\title{
Improvement and Enhancement of the Income Statement
}

\author{
Jinyu TIAN and Ziyuan ZHANG \\ North China Electric Power University, Department of Economics and Management, NCEPU, Baoding, Hebei, China, 071003 \\ 769774965@qq.com, huadianzhangzy@163.com
}

\begin{abstract}
In the current accounting standards which was implemented in 2007, with respect to traditional accounting standards, there are some major breakthroughs in the income statement, but there are still some defects such as imperfect statement indicators, arrangement problems and so on. Based on the current analysis on the insufficiency of income statement, we explore the improvement and enhancement, propose a new model of statement that cancels "operating income" and "operating expenses" to increase "gains" and "losses" project, change the structure of the income statement arrangement and fair report and disclose corporate real performance situation and profit level, which contributes the decision-makers to understand and use the income statement information.
\end{abstract}

Index Terms - The Income Statement; Problems; Improvement

\section{Introduction}

Since the 1990s, the world economy has entered a new stage, which characterizes in technology and information. International finance, international trade and international investment unprecedentedly develop.There is an increasingly competitive market, and the economic environment gets great changes. Therefore, the traditional income statement cannot effectively disclose useful accounting information, and there are increasing demands for improved income statement. Combined with current accounting standards, this paper analyzes insufficiency of income statement, combines China's conditions and international income statement, and explores improvements on the income statement.

\section{Historical Evolution of the Income Statement}

Before double-entry bookkeeping was produced, the main purpose of accounting is to protect and control the property, accounting was mainly reflects assets rather than profits. When went to the European Renaissance, with the prosperity of commerce and trade, business people began to pay attention to calculate income, then double-entry bookkeeping was produced. Before 17 centuries, because of the simplicity, sustainability business, determination of income has not yet gotten due attention. Determining earnings is quite simple, just wait until after the close of business, then ultimately income deducted the initial investment and earnings can be determined. With "continuing operations "concept and Ltd.appear, plus income behind economic consequences and gains determined the presence of a significant number of interests, the importance of income determination started to be understood to people. Because of the separation of ownership and management, there was a professional manager class, business owners were out of enterprises business, due to the shareholder has an urgent need to understand the business is good or bad, especially profitability and profit allocation; At the same time, due to the complexity of the production and management was intensified, resulting in that to calculate the profit only by comparing the beginning and end of the period of net assets in the past was outdated. So in order to reflect the outcome of production and operation between a certain period, the profit and loss statement has come into being. In the 1920s, in the United States and Britain, more and more companies have provided their income statement. In 1929, the British "Company Law" requires listed companies to prepare the income statement first officially, so that income statement become the second officially disclosed financial statements of corporate. American famous accounting scientist Littleton also repeatedly stressed the importance of the income statement in the "theoretical structure of accounting", saying that "only the income statement can reflect the success or failure of business activities this theme." Accordingly, the income statement gradually become the core of the financial report, until today, many companies, especially listed companies, regard the income statement in the first place in their annual reports.

Due to that operating results disclosed by the profit statement are net profits or losses formed by matching income and expenses for a certain period of time for companies, also known as the income statement. And because the companies subjectively want to earn rather than to lose, thus mostly referred to as the income statement. Then, it is called more popular as the income statement internationally. Our country called income statement as the gains and losses statement before 1949 , so as in the early 1950 s, later renamed the income statement. Since the reform and opening, our country experienced several reforms of enterprise accounting systems and the name of it was not the same: in 1981, 1985 and 1989, the reform of enterprise accounting system are still referred to as the income statement, then enterprise accounting system reform in 1993, which would be renamed loss table, and in 1998 "joint-stock limited liability company accounting system - accounting and Financial Statements" and later accounting reform in turn renamed it the income statement.

\section{Current Problems of the Income Statement}

The current statement is not perfect, especially in some statements and arrangements of the projects. There is space to further improve and enhance it. Therefore, this paper firstly analyzes some problems that currently exist in the income statement.

(1)The statement cannot provide a significant profit indicator: "gross profit". [1] The concept of gross profit is very important because, firstly, this concept is easy to understand and accept to the masses, while many foreign listed companies are applying this concept in the income statement; Secondly, gross profit is an important indicator of directly reflecting 
profitability of the business. Companies only have sufficient gross profits, ultimately can make more profits.

(2)It should cancel some meaningless accounting project, such as "the business tax and surcharges", "operating income" and "operating expenses." [2]

At present, China is experiencing a reform of "Business tax changed value added tax". After completing this reform, business tax will all be abolished, then the project "Business tax and surcharges" not only has no meaning, but also will mislead the laymen. Therefore, this project should be canceled.

In addition, basic guidelines clearly clarify definitions and the purposes of preparation of the income statement which is as follows: "Income statement is a corporate accounting statement in a certain accounting period which reflects operating results. The purpose of companies prepare financial statements is to truly reflect the earnings by enterprises, the costs incurred and gains and losses which shall be included in profits and other amounts and structures. Thereby it will help users analyze and evaluate the profitability, constitution and quality of enterprises. "So, we can find that elements of the income statement should include " income ", " costs ", " loss ", "profits "," profit " this five areas, while the existing income statement only reflects the " income ", " costs ", " profit " elements, as well as " operating income " and " operating expenses " two projects which are more than the basic norms standard. The presence of these two projects is unreasonable.

First, the projects "operating income" and "operating expenses" don't comply with international practices. Now that the basic principle has a clear definition of the "profits", "loss", "gains and losses that directly included in the current profit " and other concepts of the accounting elements, then there should not be the projects"operating income" and "operating expenses "that is ambiguous in the income statement, which is superfluous; Secondly, there are problems in its connotations. Since "operating income" is income, then the "income from change in fair value" and could be directly included in the profit or loss are also incomes that are not associated with the business activities. Why is not incorporated into this one, but lists separately? Similarly for "operating expenses", both are expenses, why not let "loss from change in fair value ", "impairment of assets" and other expenditures which can directly included in the profit or loss, and is not related to business activities incorporated, but let it presented separately? In my opinion, the presence of these two projects is questionable.

(3)In the financial statements, there are issues that accounting items caliber is unreasonable and uncoordinated. For example, "finance charges" in the cash flow statement is generated from financing activities, while in the income statement belongs to the business activities; So as to "investment income" and "income from changes in fair value", which in the cash flow statement belongs to investing activities and in the income statement belongs to operating activities. That is the income statement exists a problem of caliber. In this regard, the arrangement structure of the income statement should be improved to make it consistent with the caliber of the cash flow statement.

(4)That is as (3), arrangement of the statement is unreasonable. First, the "operating profit", this indicator is a profitability indicator that reflects the ability of business performance steady grow. Let the projects "income from change in fair value", "investment income", "impairment of assets" and other profit or loss from operating activities directly recognized in "operating profit" indicators that reflects the loss of the business activities, which would greatly reduces the quality of the "operating profit" indicator, does not meet the requirements of information quality of accounting care and also reduces the reliability of this indicator, easily leading to business inflated profits. Then, this arrangement will encourage enterprises to use "Income from change in fair value" project to manipulate corporate profits, smooth operating performance. Again, when financially analyzing "operating profit" indicator, project "gains from changes in fair value", "investment income" and "impairment losses on assets" will be very easy to make index fluctuate, and such fluctuations are apparently not controlled by enterprises, such as, an impairment loss due to overall market price movements, income caused by the changes in fair value, or investment income recognized in long-term equity investment under the equity method accounting,etc.. These fluctuations are very detrimental to decision-making of manager and financial analysis, also, will make evaluation of business performance unscientific and unconvincing.

For the "basic earnings per share" project in the income statement, its result is obtained by that net profit deducts of preferred dividends and then except number of common shares. But we believe that the net profit cannot represent all of the profits earnings of corporate, and should plus gains and losses that are included in the balance sheet, which is also named other comprehensive income, then there are all of the profits earnings of corporate after that. Thus arrangement of the project "basic earnings per share" is also problematic.

(5)Project "financial expenses" is unreasonable. The "Financial expenses" project in the income statement mainly accounts interest expenses costly, deposit interest income, fees of financial institutions, foreign exchange gains and losses and cash discounts. In these items, financial analysis generally only analyzes the interest expenses costly this one, the others usually omitted. But "interest expense" project which is a more important cost do not separately presented in the income statement, I think it is inappropriate. If you do not present separately "interest expense", it will be difficult to financial analysis.

\section{Improvement and Enhancement of the Income Statement}

(1)The current income statement firstly calculate operating profit, operating profit here is revenue minus costs and related taxes, also deduct the cost of sales, administrative expenses and financial costs. And I take a opinion that the concept of gross profit should be introduced firstly to the income statement, that is revenue - operating costs = operating 
gross profit. Because, first, this concept is easy to understand and accept to the masses; secondly, gross profit is an important indicator of directly reflecting profitability of the business. Companies only have sufficient gross profits, ultimately can make more profits. This requires to move the "Business tax and surcharges" after and increase the "gross profit" indicator.

(2)Cancel "business tax and surcharges", "operating income" and "operating expenses" and increase "profits" and "losses" projects. As the "Business tax changed value added tax"reform is taking, value added tax will all all be canceled, so this project should be canceled, which taxes will all be included in the "cost of sales". In China, the income statement does not include "gains" and "losses" these two projects, I believe that these two projects should be listed separately, while simultaneously cancel "operating income" and "operating expenses" projects, which will included in the "gains" and "losses" projects respectively.

(3)In calculating the "operating profit", let the "financial expenses", "impairment of assets", "gains from changes in fair value", "investment income" post to the following position of "operating profit", and to make it more reliable, and more in line with the requirements of prudence. In this case, the operating profit data disclosed out of corporate will be more real and comparable. The "income from change in fair value" and other projects are not closely linked with daily activities of enterprises, which belongs to a non-operating gains and losses, after removed, operating profit equals operating income minus operating expenses, which will be more realistic. After this improvement, caliber issues of "financial expenses", "income from change in fair value", "investment income" and other projects between the income statement and cash flow statement will also be eliminated, and the caliber can be more reasonable and coordinate.

(4)Adjust "financial expenses" items. First present separately "interest expense" project, make the deposit interest income offset "management fees" project, include the financial institution fees into the "management fees" and separately present "foreign exchange gains" project. With such improvements, it is in favor of some calculations of financial indicators and analysis of financial aspects, as well as to facilitate information users to understand the real return on investment, easier to understand and use information.

(5)Move the "earnings per share" project to the under of the "comprehensive income", because "the basic earnings per share" should be obtained by that net profit plus the value of other comprehensive income and minus preferred stock dividends and then except number of common shares, thus the result is the most realistic and reasonable, which will help information users to make decisions. table:

The improved income statement is shown in the following
TABLE I Income Statement

\begin{tabular}{|l|l|l|}
\hline Project & $\begin{array}{l}\text { Current } \\
\text { Amount }\end{array}$ & $\begin{array}{l}\text { Previous } \\
\text { period }\end{array}$ \\
\hline 1. Operating income & & \\
\hline Minus: Operating costs & & \\
\hline 2.Gross profit & & \\
\hline Minus:Management fees & & \\
\hline Sales expense & & \\
\hline 3.Operating profit (loss '-' for loss) & & \\
\hline Plus: Gains & & \\
\hline $\begin{array}{l}\text { Including: Income from change in fair } \\
\text { value (loss '-' for loss) }\end{array}$ & & \\
\hline Investment income & & \\
\hline $\begin{array}{l}\text { Including: Investment income of } \\
\text { associates and joint ventures }\end{array}$ & & \\
\hline Exchange gains (losses '-' for loss) & & \\
\hline Minus:Losses & & \\
\hline Impairment of assets & & \\
\hline Interest expense & & \\
\hline 4.Total profit (loss '-' for loss) & & \\
\hline Minus:Income tax expense & & \\
\hline 5.Net profit (net loss '-' for loss) & & \\
\hline 6.Other comprehensive income & & \\
\hline 7.Comprehensive Income & & \\
\hline 8.Earnings per share & & \\
\hline (A) Basic earnings per share & & \\
\hline (B) Diluted earnings per share & & \\
\hline
\end{tabular}

\section{Conclusion}

In the current accounting standards which was implemented in 2007, with respect to traditional accounting standards, there are some major breakthroughs in the income statement, but there are still some defects such as imperfect statement indicators, arrangement problems and so on. Based on the current analysis on the insufficiency of income statement, we explore the improvement and enhancement, propose a new model of statement that cancels "operating income" and "operating expenses" to increase "gains" and "losses" project, change the structure of the income statement arrangement and fair report and disclose corporate real performance situation and profit level, which contributes the decision-makers to understand and use the income statement information

\section{References}

[1] Yang Fangwen, "Improvement of income statement," Economics Forum, vol. 17, pp. 81-82, 2003.

[2] Zhou Qiongfang and Xu Hong, "Limitations and improvement of income statement," Chongqing University of Technology (social sciences), vol. 09, pp. 41-45, 2011.

[3] Zhang Xueqi, "To improve the income statement of listed companies under the new accounting standards," Statistics and Consultation, vol. 04, 2007, pp. 40-41. 